\title{
Phytoprotection
}

\section{Yield reductions in grain maize associated with the presence of European corn borer and Gibberella stalk rot in Québec}

\section{Hudon, G. Bourgeois, G. Boivin et D. Chez}

Volume 73, numéro 3, 1992

URI : https://id.erudit.org/iderudit/706026ar

DOI : https://doi.org/10.7202/706026ar

Aller au sommaire du numéro

Éditeur(s)

Société de protection des plantes du Québec (SPPQ)l

ISSN

0031-9511 (imprimé)

1710-1603 (numérique)

Découvrir la revue

Citer cet article

Hudon, M., Bourgeois, G., Boivin, G. \& Chez, D. (1992). Yield reductions in grain maize associated with the presence of European corn borer and Gibberella stalk rot in Québec. Phytoprotection, 73(3), 101-110.

https://doi.org/10.7202/706026ar
Résumé de l'article

L'effet d'une infestation de la pyrale du maïs (Ostrinia nubilalis) [Lepidoptera: Pyralidae] et d'une infection de la fusariose des tiges causée par Gibberella zeae sur le rendement de huit lignées de maïs grain (Zea mays), de deux hybrides commerciaux et de six hybrides expérimentaux a été évalué de 1975 à 1980. Trois critères ont été utilisés: la criblure du feuillage, les dégâts totaux des plantes à la récolte et le rapport de la longueur des galeries creusées par les chenilles de pyrale dans les tiges sur la hauteur totale du plant. Pour la plupart des critères, les cultivars étaient significativement différents et l'infestation artificielle de pyrale du maïs a eu un effet presqu'à chaque année. Bien que le G. zeae ait eu un effet significatif sur les dégâts totaux à la récolte et le rendement en grain du maïs, aucune relation n'a pu être établie entre la maladie et la pyrale du maïs. 


\title{
Yield reductions in grain maize associated with the pre- sence of European corn borer and Gibberella stalk rot in Québec
}

\author{
Marcel Hudon', Gaétan Bourgeois ${ }^{1}$, Guy Boivin', and Daniel Chez ${ }^{2}$
}

Received 1992-03-31; accepted 1992-11-03

The impact of European corn borer (Ostrinia nubilalis) [Lepidoptera: Pyralidae] infestation and stalk rot infection caused by Gibberella zeae on yield of eight grain maize (Zea mays) inbreds, two commercial and six experimental hybrids was evaluated from 1975 to 1980 . Three criteria were used: leaf feeding, total plant damage at harvest and tunnel length/plant height ratio. For most criteria, the cultivars were significantly different and the artificial European corn borer infestation had an effect almost every year. Although $G$. zeae can have a significant effect on plant damage at harvest and yield of grain maize, no consistent link was found between stalk rot and European corn borer.

Hudon, M., G. Bourgeois, G. Boivin et D. Chez. 1992. Réductions des rendements du maïs-grain associées à la présence de la pyrale du maïs et de la fusariose des tiges au Québec. PHYTOPROTECTION 73: 101-110.

L'effet d'une infestation de la pyrale du maïs (Ostrinia nubilalis) [Lepidoptera: Pyralidae] et d'une infection de la fusariose des tiges causée par Gibberella zeae sur le rendement de huit lignées de maïs grain (Zea mays), de deux hybrides commerciaux et de six hybrides expérimentaux a été évalué de 1975 à 1980. Trois critères ont été utilisés: la criblure du feuillage, les dégâts totaux des plantes à la récolte et le rapport de la longueur des galeries creusées par les chenilles de pyrale dans les tiges sur la hauteur totale du plant. Pour la plupart des critères, les cultivars étaient significativement différents et l'infestation artificielle de pyrale du maïs a eu un effet presqu'à chaque année. Bien que le $G$. zeae ait eu un effet significatif sur les dégâts totaux à la récolte et le rendement en grain du maïs, aucune relation n'a pu être établie entre la maladie et la pyrale du maïs.

\section{INTRODUCTION}

Stalk-boring insects and stalk rot organisms are among the most important causes limiting maize (Zea mays L.) production in the world (Dicke and Guthrie

1. Research Station, Agriculture Canada, 430 , boul. Gouin, Saint-Jean-sur-Richelieu, Québec, Canada J3B 3E6. Contribution No. 335/92.08.01R

2. Ministère de l'Agriculture, des Pêcheries et de l'Alimentation du Québec,

2700, rue Einstein, Sainte-Foy, Québec,

Canada G1P 3W8
1988; Shurtleff 1980). These organisms become major factors in determining the quality, yield and harvestability of the crop, and their impact varies with geographical area and climate. Stalk rots are caused by several pathogens, particularly the fungi Fusarium spp. (Gibberella). Gibberella stalk rot induced by Gibberella zeae (Schw.) Petch (perfect stage of Fusarium graminearum Schw.) is the main pathogen in Ontario (McKeen 1951) and Québec (Chiang et al. 1987). Yield reduction may vary with the hybrid (Wilcoxson 1962) and the inbred lines (Smith and Madsen 1949), the pathogenicity of fun- 
gus, the intensity of infection per plant and the season (Michaelson and Christensen 1953). Many organisms are vectors of Gibberella stalk rot, particularly the European corn borer (ECB), Ostrinia nubilalis (Hübner) [Lepidoptera: Pyralidae], which remains among the most destructive insects of maize in Canada (Hudon and LeRoux 1986).

Christensen and Schneider (1950) and Taylor (1952) were the first to report an association between ECB infestation and infection by ear and stalk rots. Incidence and severity of stalk rots increase with the presence of $O$. nubilalis (Bergstrom et al. 1983; Christensen and Schneider 1950; Keller et al. 1986). In Minnesota, Christensen and Schneider (1950) investigated organisms that developed in maize plants after ECB infestation. They found that Fusarium spp. were the most common pathogens isolated from injured plants and also from internal parts of living and dead borers (Dicke and Guthrie 1988). Maize inbred lines and hybrids normally resistant to stalk rots caused by Diplodia and Fusarium spp. (Gibberella) were readily infected when attacked by 0 . nubilalis (Jarvis et al. 1984; Krueger and
Weiler 1977). Jarvis et al. (1982) reported that Diplodia stalk rot damage was highest under high levels of $O$. nubilalis infestation. Interactive effects of ECB and the common stalk rot species have been reported by several authors (Bergstrom et al. 1983; Chez et al. 1977; Krueger and Weiler 1977) and this evidence suggests that this insect-disease complex is so intimately linked that any yield reduction studies, breeding programs, or other control strategies focusing on a single fungus or insect are incomplete without detailed consideration of the concomitant role of other pests (Keller et al. 1986). More recently, Nyhus et al. (1988) reported that the level of resistance to ECB and Diplodia stalk rot in the population crosses of two maize synthetics (BSAA and BSBB) suggested that the genes governing this resistance are acting in an additive manner. Selection for resistance to both traits was associated with increased physical stalk strength as well as for resistance to stalkrotting organisms.

The following study was undertaken to determine the interactive effects of Gibberella stalk rot and the ECB on yield reduction and plant damage of inbred

Table 1. Inbred lines, experimental and commercial hybrids evaluated during the period 19751980, L'Acadie, Québec

\begin{tabular}{|c|c|c|c|c|c|c|c|}
\hline \multirow{2}{*}{$\begin{array}{l}\text { Maize } \\
\text { cultivars }\end{array}$} & \multirow{2}{*}{$\begin{array}{l}\text { Leaf feeding } \\
\text { rating }^{a}\end{array}$} & \multicolumn{6}{|c|}{ Years } \\
\hline & & 1975 & 1976 & 1977 & 1978 & 1979 & 1980 \\
\hline \multicolumn{8}{|l|}{ Inbred lines } \\
\hline $\begin{array}{l}\text { CO } 239 \\
\text { Q } 191 \\
\text { T } 341 \\
\text { CH } 591-36 \\
\text { Bc } 23 \\
\text { Bc } 9 A \\
\text { Bc } 14 \\
\text { Bc } 6635\end{array}$ & $\begin{array}{l}R \\
R \\
R \\
R \\
S \\
I \\
S \\
R\end{array}$ & $\begin{array}{l}X \\
X\end{array}$ & $\begin{array}{l}x \\
x\end{array}$ & $\begin{array}{l}X \\
X\end{array}$ & $\begin{array}{l}X \\
X\end{array}$ & $\begin{array}{l}X \\
X \\
X \\
X\end{array}$ & $\begin{array}{l}X \\
X \\
X \\
X\end{array}$ \\
\hline \multicolumn{8}{|l|}{ Hybrid lines } \\
\hline $\begin{array}{l}\text { Stewart } 2606 \\
\text { Stewart } 2704 \\
\text { MR21 X ZPR2077 } \\
\text { R588 X T146 } \\
\text { Bc } 9 A \text { X Bc } 23 \\
\text { Bc } 14 \times \text { Xc } 23 \\
\text { Bc } 6635 \times \text { Bc } 23 \\
\text { Bc } 9 A \text { X Bc } 6635\end{array}$ & $\begin{array}{l}R \\
S \\
\text { I-S } \\
\text { I-R } \\
\text { I-S } \\
\text { S } \\
\text { R-S } \\
\text { I-R }\end{array}$ & $\begin{array}{l}x \\
x\end{array}$ & $\begin{array}{l}x \\
x\end{array}$ & & $x$ & $\begin{array}{l}X \\
X \\
X \\
X\end{array}$ & $\begin{array}{l}X \\
X \\
X \\
X\end{array}$ \\
\hline
\end{tabular}

${ }^{a} \mathrm{R}=$ resistant, $\mathrm{I}=$ Intermediate, $\mathrm{S}=$ susceptible. 
lines, experimental, and commercial hybrids of maize.

\section{MATERIALS AND METHODS}

Grain maize plots were established on a Macdonald clay loam soil at the experimental farm of Agriculture Canada at L'Acadie. The study was conducted for $6 \mathrm{yr}$ (1975-1980), using a randomized complete block design with four replications each year. The treatments were arranged as a factorial experiment with three factors: maize lines or hybrids, ECB infestation, and G. zeae infection. The number of levels in the maize lines or hybrids factor as well as the lines or hybrids themselves were not the same from one year to the other (Table 1). For these reasons, a statistical analysis was done for each year, with a general linear model procedure (SAS Institute Inc. 1985). The factors ECB infestation and G. zeae infection had two levels each. Levels of the ECB infestation were either an insecticide-treated or an artificial infestation, and levels of G. zeae infection were natural infection and artificial inoculation with $G$. zeae.

Most cultivars evaluated in this study are considered of the early type in their flowering and harvest maturity, but varied in their resistance or tolerance to the ECB from very resistant, to resistant, intermediate and susceptible. Some years, certain cultivars had to be replaced due to a shortage of seeds, particularly for the hybrids, but for the last $2 \mathrm{yr}$, all materials remained the same (Table 1 ).

Each genotype was submitted to the four combinations of treatments mentioned previously. The insecticide-treated plants, including plants with natural infection of $G$. zeae, received two applications of granular carbofuran (Furadan 10G) at $1.1 \mathrm{~kg}$ a.i. ha-1, made at maximum natural egg laying of the univoltine strain of the borer that occur normally during the $2^{\text {nd }}$ and $3^{\text {rd }}$ week of July. The artificial ECB infestation consisted in the deposition of 4 egg masses plant ${ }^{-1}$ (100 eggs in total) for the inbreds and 6 egg masses plant ${ }^{-1}$ (150 eggs in total) for the hybrids into the whorl of each plant in two or three lots of two masses each, at 2-d intervals, during the middle of the natural egg laying period of the borer (normally mid-July). ECB egg masses were obtained according to the rearing technique of Guthrie (1971).

Plants were artificially inoculated with G. zeae during or after pollination, at the second internode of the plants using the toothpick method (Young 1943). The inoculum preparation and technique were similar to that described by Chiang et al. (1987).

Except for 1976, where two rows of plants were used, each plot consisted of a single row of $8 \mathrm{~m}$ long, hand-planted about mid-May at a rate of 61775 seeds $\mathrm{ha}^{-1}$. All plots were spaced $90 \mathrm{~cm}$ apart. The number of plants sampled in each plot varied from 10 (1979) to 30 (1978) depending on the number of inbreds and hybrids evaluated during that year. An herbicide combination of atrazine at 1.35 $\mathrm{kg}$ a.i. ha-1 (2-chloro-4-ethylamino-6-isopropylamino-s -triazine) with alachlor at $2.64 \mathrm{~kg}$ a.i. ha-1 (2-chloro-2'-6'-diethyl- $N$ (methoxymethyl)-acetamilide) was applied to the whole field before planting. Plots were fertilized according to recommendations.

Plants were rated for ECB leaf feeding approximately $4 \mathrm{wk}$ after the last egg mass deposition using a 9-class visual rating system ( $1=$ no feeding, $9=$ extensive feeding) (Guthrie et al. 1960), and for total plant damage and breakage at harvest, using a 10-class visual rating system ( $1=$ uninfested plant, $10=$ plant broken below the ear) (Hudon et al. 1979). Plant height was recorded at tasselling in July. The criterion, "tunnel length over plant height ration (TPHR) is the total length of tunnels in $\mathrm{cm}$ in a plant divided by its height. It is considered a reliable criterion for evaluating univoltine ECB damage and maize resistance or tolerance to $O$. nubilalis (Hudon and Chiang 1991). All plots were hand-harvested each year by midOctober and yield data consisted of the kernel weight $\left(\mathrm{g} \mathrm{plant}^{-1}\right)$ of the ear of each plant dried at $60^{\circ} \mathrm{C}$ for $3 \mathrm{~d}$ and shelled.

\section{RESULTS AND DISCUSSION}

The $F$ values for the comparison of leaf feeding, plant damage, TPHR and yield between the treatments and their degree 
Table 2. F values for the effects of cultivars, stalk rot and ECB infestation on leaf feeding, plant damage, tunnel length over plant height ratio (TPHR) and grain maize yield at L'Acadie, Québec from 1975 to 1980

\begin{tabular}{|c|c|c|c|c|c|c|}
\hline \multirow[b]{2}{*}{ Year } & \multirow[b]{2}{*}{ Source } & \multirow[b]{2}{*}{$\begin{array}{l}\text { Degree of } \\
\text { freedom }\end{array}$} & \multicolumn{4}{|c|}{$F$ values } \\
\hline & & & $\begin{array}{l}\text { Leaf } \\
\text { feeding }\end{array}$ & $\begin{array}{c}\text { Plant } \\
\text { damage }\end{array}$ & $\mathrm{TPHR}^{\mathrm{c}}$ & Yield \\
\hline \multirow[t]{10}{*}{1975} & Blocks & 3 & $2.98^{* a}$ & 2.16 & 2.63 & 0.81 \\
\hline & Cultivars(C) & 3 & 1.71 & $22.29 * * *$ & $7.03 * * *$ & $533.85^{* * *}$ \\
\hline & Stalk rot $(\mathrm{Sr})$ & 1 & 0.42 & 0.02 & $14.42^{* * *}$ & 3.57 \\
\hline & ECB & 1 & $270.02 * * *$ & $345.24 * * *$ & $1366.73^{* * *}$ & $495.90 * * *$ \\
\hline & $\mathrm{C} \times \mathrm{Sr}$ & 3 & 0.26 & 0.75 & 0.31 & 2.12 \\
\hline & $C \times E C B$ & 3 & 1.71 & $8.98 * * *$ & $3.41^{*}$ & 0.96 \\
\hline & Sr X ECB & 1 & 0.42 & $6.02^{*}$ & $27.23^{* * *}$ & $7.00^{* *}$ \\
\hline & $C \times \operatorname{Sr} \times E C B$ & 3 & 0.26 & 0.48 & 0.77 & 1.56 \\
\hline & Error & 45 & & & & \\
\hline & Total & 63 & & & & \\
\hline \multirow[t]{10}{*}{1976} & Blocks & 3 & $-b$ & - & $3.15^{*}$ & 0.66 \\
\hline & Cultivars & 3 & - & - & $10.53^{* * *}$ & $27.92 * * *$ \\
\hline & Stalk rot & 1 & - & - & $13.23^{* * *}$ & 0.18 \\
\hline & ECB & 1 & - & - & $367.06^{* * *}$ & $8.30^{* *}$ \\
\hline & $\mathrm{C} \times \mathrm{Sr}$ & 3 & - & - & $7.36^{* * *}$ & 0.14 \\
\hline & $C \times E C B$ & 3 & - & - & $12.67 * * *$ & 0.96 \\
\hline & Sr X ECB & 1 & - & - & $13.23^{* * *}$ & 0.12 \\
\hline & $\mathrm{C} \times \mathrm{Sr} \times \mathrm{ECB}$ & 3 & - & - & $7.36 * * *$ & 0.38 \\
\hline & Error & 45 & & & & \\
\hline & Total & 63 & & & & \\
\hline \multirow[t]{10}{*}{1977} & Blocks & 3 & 0.69 & 0.61 & 0.40 & 1.18 \\
\hline & Cultivars & 1 & $20.35^{* * *}$ & 1.36 & $15.73^{* * *}$ & $24.96 * * *$ \\
\hline & Stalk rot & 1 & 3.83 & 0.26 & 0.13 & 0.31 \\
\hline & ECB & 1 & 1.85 & $7.23^{* *}$ & $32.16^{* * *}$ & 2.05 \\
\hline & $\mathrm{C} \times \mathrm{Sr}$ & 1 & 0.18 & 2.47 & 0.07 & 0.31 \\
\hline & $C \times E C B$ & 1 & $8.37^{* *}$ & 0.16 & $12.75^{* *}$ & 3.47 \\
\hline & Sr X ECB & 1 & 0.46 & 0.06 & 0.06 & 1.31 \\
\hline & $\mathrm{C} \times \mathrm{Sr} \times \mathrm{ECB}$ & 1 & 1.04 & 0 & 0.13 & 1.34 \\
\hline & Error & 21 & & & & \\
\hline & Total & 31 & & & & \\
\hline \multirow[t]{10}{*}{1978} & Blocks & 3 & 0.34 & 1.24 & 2.24 & $8.98^{* * *}$ \\
\hline & Cultivars & 2 & $7.72^{* *}$ & $32.13^{* * *}$ & $10.36^{* * *}$ & $268.68^{* * *}$ \\
\hline & Stalk rot & 1 & 0.01 & $4.42^{*}$ & 0.85 & 3.30 \\
\hline & ECB & 1 & $635.72^{* * *}$ & $11.80^{* *}$ & $34.97 * * *$ & 0.57 \\
\hline & $\mathrm{C} \times \mathrm{Sr}$ & 2 & 0.07 & 1.13 & 1.98 & 0.44 \\
\hline & $C \times E C B$ & 2 & $9.05^{* * *}$ & 2.12 & $11.00 * * *$ & 0.48 \\
\hline & $\mathrm{Sr} \times \mathrm{ECB}$ & 1 & 0.06 & 0.18 & 0.67 & 0.04 \\
\hline & $C \times \operatorname{Sr} \times E C B$ & 2 & 0.20 & 0.34 & 2.14 & 0.36 \\
\hline & Error & 33 & & & & \\
\hline & Total & 47 & & & & \\
\hline \multirow[t]{10}{*}{1979} & Blocks & 3 & 0.61 & 2.07 & 1.14 & 1.24 \\
\hline & Cultivars & 7 & $12.87^{* * *}$ & $3.88^{* *}$ & $13.00 * * *$ & $88.04^{* * *}$ \\
\hline & Stalk rot & 1 & 0.28 & $23.52^{* * *}$ & 1.66 & $8.74^{* *}$ \\
\hline & $\mathrm{ECB}$ & 1 & $763.23^{* * *}$ & 1.28 & $318.59 * * *$ & $8.96 * *$ \\
\hline & $\mathrm{C} \times \mathrm{Sr}$ & 7 & 1.46 & 1.46 & 1.18 & 0.80 \\
\hline & $C \times E C B$ & 7 & $11.56^{* * *}$ & $5.03^{* * *}$ & $11.10 * * *$ & 1.34 \\
\hline & Sr X ECB & 1 & 0.08 & $12.51^{* * *}$ & $8.55^{* *}$ & 0 \\
\hline & $\mathrm{C} \times \mathrm{Sr} \times \mathrm{ECB}$ & 7 & 1.13 & 2.02 & 1.81 & 0.73 \\
\hline & Error & 93 & & & & \\
\hline & Total & 127 & & & & \\
\hline
\end{tabular}


Table 2. (suite)

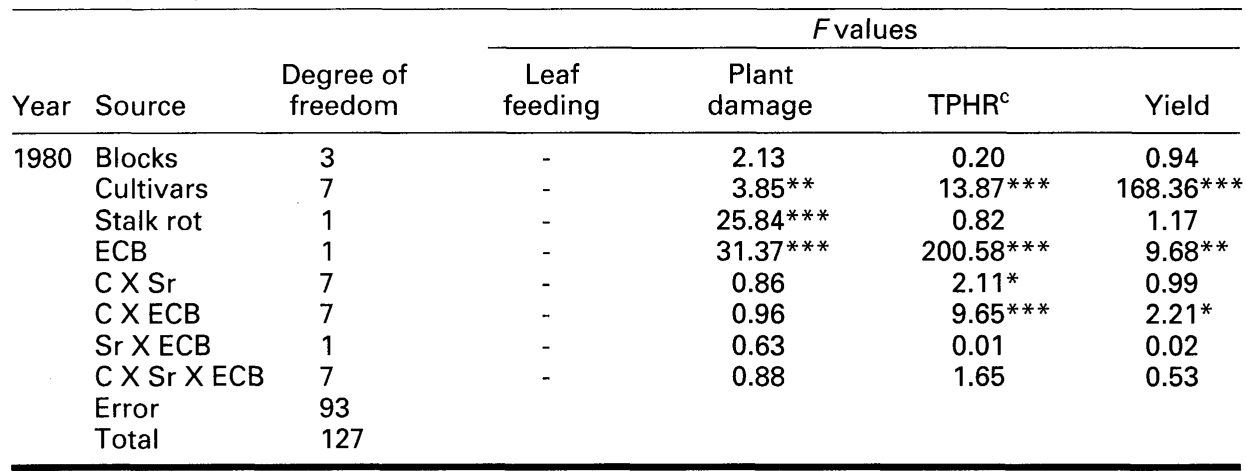

a $* *^{*}, *^{* *}$ : significant at the $0.05,0.01$, and 0.001 levels, respectively.

${ }^{b}$ Data not available.

c TPHR is the total lengthof tunnels in $\mathrm{cm}$ in a plant divided by its height.

of significance are presented in Table 2. The effect of ECB factor on leaf feeding was significant $(P \leq 0.001)$ except in 1977. This result indicates that the manual infestation of plants using egg masses yielded young larvae and that the insecticide treatments used were able to keep the population of ECB at a low level in the treated plots. The absence of effect in 1977 might be due to the cultivars Q191 and $\mathrm{CH} 591-36$ used that year, both of which are partially resistant to leaf feeding by $O$. nubilalis (Hudon et al. 1979). The effect of cultivar was significant $(P \leq 0.01)$ except in 1975 largely because the hybrids (susceptible) and inbreds (resistant) reacted differently to ECB attack. The interactions between cultivar and ECB were also significant $(P \leq 0.01)$ except in 1975 (Table 2). Stalk rot had no significant effect on leaf feeding by ECB and there was no significant interactions between stalk rot, ECB and cultivar (Table 2).

ECB presence increased significantly the leaf feeding on most cultivars and years. However, only one out of 17 tests showed a significant increase in leaf feeding due to the presence of stalk rot (Table $3)$. This observation indicates that infection by stalk rot does not modify the palatability of maize plant parts to young ECB larvae.

Plant damage at harvest reflected injury done during the season by both ECB larvae and stalk rot. The cultivars were significantly different $(P \leq 0.01)$ except in 1977. The manual infestation by ECB also had an effect every year except 1979 (Ta- ble 2). In 1978, 1979 and 1980, stalk rot was a significant factor $(P \leq 0.05)$ indicating that infection by this pathogen weakens plants and increases breakage near harvest time. This phenomenon has been observed previously in Québec by Chez et al. (1977). Significant interactions were found between cultivar and ECB and between stalk rot and ECB in 1975 and 1979.

A different picture arose when the results for plant damage at harvest are analyzed for each cultivar (Table 4). Plant damage was related to artificial ECB infestations in some years but results were not consistent. The four hybrids tested in 1979 showed no significant effects while three of the same cultivars showed an effect in 1980. Some significant effects were also observed for the presence of stalk rot. However, five out the seven significant effects indicated that the presence of stalk rot decreased plant damage at harvest. Perhaps infected plants become less suitable for ECB larval development and that decreased survival or slower development of larvae result in lower stalk damage.

The TPHR is more indicative of the acceptance of a plant by ECB larvae and their subsequent survival. Using this criteria, again cultivar and artifical infestation of ECB had a highly significant effect $(P \leq$ 0.001 ) every year. In 1975 and 1976, the artifical infection of stalk rot had a significant effect $(P \leq 0.001)$ indicating that an infected plant is less acceptable for ECB development. For these $2 \mathrm{yr}$, the interaction between stalk rot and ECB was also significant $(P \leq 0.001)$ (Table 2$)$. 
Table 3. Mean value of leaf feeding for plots with and without European corn borer and stalk rot

\begin{tabular}{|c|c|c|c|c|c|}
\hline \multirow[b]{3}{*}{ Year } & \multirow[b]{3}{*}{ Cultivars } & \multicolumn{4}{|c|}{ Mean leaf feeding rating ${ }^{a}$} \\
\hline & & \multicolumn{2}{|c|}{ European corn borer } & \multicolumn{2}{|c|}{ Stalk rot } \\
\hline & & With & Without & With & Without \\
\hline 1975 & $\begin{array}{l}\text { CO } 239 \\
\text { Q } 191 \\
\text { Stewart } 2606 \\
\text { Stewart } 2704\end{array}$ & $\begin{array}{l}2.69 * * * b \\
3.25 * * * \\
2.74 * * * \\
2.61 * * *\end{array}$ & $\begin{array}{l}1.00 \\
1.00 \\
1.00 \\
1.00\end{array}$ & $\begin{array}{l}1.82 \\
2.22 \\
1.95 \\
1.80\end{array}$ & $\begin{array}{l}1.86 \\
2.04 \\
1.79 \\
1.81\end{array}$ \\
\hline 1977 & $\begin{array}{l}\text { Q } 191 \\
\text { CH } 591-36\end{array}$ & $\begin{array}{l}2.47 * \\
1.38\end{array}$ & $\begin{array}{l}1.84 \\
1.60\end{array}$ & $\begin{array}{l}2.27 \\
1.66 *\end{array}$ & $\begin{array}{l}2.04 \\
1.31\end{array}$ \\
\hline 1978 & $\begin{array}{l}\text { Bc } 23 \\
\text { Bc } 9 A \\
\text { Bc } 9 A \times \text { Bc } 23\end{array}$ & $\begin{array}{l}4.42 * * * \\
4.52 * * * \\
5.80 * * *\end{array}$ & $\begin{array}{l}1.08 \\
1.02 \\
1.00\end{array}$ & $\begin{array}{l}2.77 \\
2.76 \\
3.36\end{array}$ & $\begin{array}{l}2.71 \\
2.79 \\
3.44\end{array}$ \\
\hline 1979 & $\begin{array}{l}\text { Bc } 23 \\
\text { Bc } 9 A \\
\text { Bc } 14 \\
\text { Bc } 6635 \\
\text { Bc } 9 \text { A X Bc } 23 \\
\text { Bc } 14 \times \text { Bc } 23 \\
\text { Bc } 6635 \times \text { Bc } 23 \\
\text { Bc } 9 \text { A X Bc } 6635\end{array}$ & $\begin{array}{l}5.90 * * * \\
6.29 * * * \\
8.18 * * * \\
3.52 * * * \\
4.61 * * * \\
5.84 * * * \\
5.13 * * * \\
4.71 * * *\end{array}$ & $\begin{array}{l}1.46 \\
1.69 \\
1.72 \\
1.50 \\
1.72 \\
1.50 \\
1.79 \\
1.55\end{array}$ & $\begin{array}{l}4.15 \\
3.84 \\
5.21 \\
2.34 \\
3.10 \\
3.60 \\
3.28 \\
3.33\end{array}$ & $\begin{array}{l}3.21 \\
4.14 \\
4.70 \\
2.69 \\
3.24 \\
3.74 \\
3.62 \\
2.92\end{array}$ \\
\hline
\end{tabular}

a Leaf feeding rating: 1 = no feeding, 9 = extensive feeding.

$b{ }^{*}, *^{* *}$ : significant at the 0.05 and 0.001 levels, respectively.

Table 4. Mean value of plant damage for plots with and without European corn borer and stalk rot

\begin{tabular}{|c|c|c|c|c|c|}
\hline \multirow[b]{3}{*}{ Year } & \multirow[b]{3}{*}{ Cultivars } & \multicolumn{4}{|c|}{ Mean plant damage rating ${ }^{a}$} \\
\hline & & \multicolumn{2}{|c|}{ European corn borer } & \multicolumn{2}{|c|}{ Stalk rot } \\
\hline & & With & Without & With & Without \\
\hline 1975 & $\begin{array}{l}\text { CO } 239 \\
\text { O } 191 \\
\text { Stewart } 2606 \\
\text { Stewart } 2704\end{array}$ & $\begin{array}{l}5.29 * * * b \\
6.44 * * * \\
5.16 * * * \\
3.33 * * *\end{array}$ & $\begin{array}{l}2.15 \\
2.22 \\
1.81 \\
1.54\end{array}$ & $\begin{array}{l}4.23 \\
4.14 \\
3.46 \\
2.43\end{array}$ & $\begin{array}{l}3.89 \\
4.52 \\
3.51 \\
2.44\end{array}$ \\
\hline 1977 & $\begin{array}{l}\text { Q } 191 \\
\text { CH } 591-36\end{array}$ & $\begin{array}{l}2.05 * \\
1.66\end{array}$ & $\begin{array}{l}1.29 \\
1.10\end{array}$ & $\begin{array}{l}1.41 \\
1.51\end{array}$ & $\begin{array}{l}1.92 \\
1.25\end{array}$ \\
\hline 1978 & $\begin{array}{l}\text { Bc } 23 \\
\text { Bc } 9 A \\
\text { Bс } 9 A \times \text { Bc } 23\end{array}$ & $\begin{array}{l}1.85 * * \\
2.80 * * \\
2.42\end{array}$ & $\begin{array}{l}1.14 \\
2.40 \\
2.31\end{array}$ & $\begin{array}{l}1.62 \\
2.84 * * \\
2.39\end{array}$ & $\begin{array}{l}1.38 \\
2.36 \\
2.35\end{array}$ \\
\hline 1979 & $\begin{array}{l}\text { Bc } 23 \\
\text { Bc } 9 A \\
\text { Bc } 14 \\
\text { Bc } 6635 \\
\text { Bc } 9 A \times \text { Bc } 23 \\
\text { Bc } 14 \times \text { Bc } 23 \\
\text { Bc } 6635 \times \text { Bc } 23 \\
\text { Bc } 9 A \times \text { Bc } 6635\end{array}$ & $\begin{array}{l}1.40 \\
2.28 \\
1.46 * * * \\
1.08 \\
2.17 \\
2.90 \\
1.93 \\
1.60\end{array}$ & $\begin{array}{l}1.72 \\
1.84 \\
4.10 \\
1.58 \\
1.85 \\
1.94 \\
1.72 \\
1.62\end{array}$ & $\begin{array}{l}1.82 \\
2.41 \\
3.71 \\
1.37 \\
2.59 \\
2.99 \\
2.33 \\
1.70\end{array}$ & $\begin{array}{l}1.30 \\
1.70 \\
1.85 \\
1.29 \\
1.44 \\
1.85 \\
1.32 \\
1.52\end{array}$ \\
\hline 1980 & $\begin{array}{l}\text { Bc } 23 \\
\text { Bc } 9 \text { A } \\
\text { Bc } 14 \\
\text { Bc } 6635 \\
\text { Bc } 9 A \times \text { Bc } 23 \\
\text { Bc } 14 \times \text { Bc } 23 \\
\text { Bc } 6635 \times \text { Bc } 23 \\
\text { Bc } 9 \text { A X Bc } 6635\end{array}$ & $\begin{array}{l}2.35 \\
3.67 \\
2.81 * * \\
2.73 \\
2.84 \\
3.58 * * \\
2.42 * * * \\
3.19 * * *\end{array}$ & $\begin{array}{l}1.75 \\
3.02 \\
1.52 \\
2.12 \\
2.46 \\
1.79 \\
1.26 \\
2.09\end{array}$ & $\begin{array}{l}1.84 \\
2.52 \\
1.67 * \\
2.25 \\
2.15^{*} \\
2.01^{*} \\
1.45^{*} \\
2.40^{*}\end{array}$ & $\begin{array}{l}2.26 \\
4.19 \\
2.68 \\
2.61 \\
3.15 \\
3.25 \\
2.24 \\
2.88\end{array}$ \\
\hline
\end{tabular}

alant damage rating: 1 = clean plant, $10=$ plant broken below the ear.

$b * *^{*},{ }^{* *}$ : significant at the $0.05,0.01$, and 0.001 levels, respectively. 
Table 5. Mean value of tunnel length over plant height ratio (TPHR) for plots with and without European corn borer and stalk rot

\begin{tabular}{|c|c|c|c|c|c|}
\hline \multirow[b]{3}{*}{ Year } & \multirow[b]{3}{*}{ Cultivars } & \multicolumn{4}{|c|}{ Mean TPHR ${ }^{a}$} \\
\hline & & \multicolumn{2}{|c|}{ European corn borer } & \multicolumn{2}{|c|}{ Stalk rot } \\
\hline & & With & Without & With & Without \\
\hline 1975 & $\begin{array}{l}\text { CO } 239 \\
\text { O } 191 \\
\text { Stewart } 2606 \\
\text { Stewart } 2704\end{array}$ & $\begin{array}{l}0.349 * * * b \\
0.436 * * * \\
0.456 * * * \\
0.422 * * *\end{array}$ & $\begin{array}{l}0.016 \\
0.038 \\
0.031 \\
0.031\end{array}$ & $\begin{array}{l}0.155 * * * \\
0.221 \\
0.221 \\
0.212\end{array}$ & $\begin{array}{l}0.209 \\
0.253 \\
0.266 \\
0.241\end{array}$ \\
\hline 1976 & $\begin{array}{l}\text { CO } 239 \\
\text { T } 341 \\
\text { MR21 X ZPR2077 } \\
\text { R588 X T146 }\end{array}$ & $\begin{array}{l}0.153 * * * \\
0.197 * * * \\
0.139 * * * \\
0.080 * * *\end{array}$ & $\begin{array}{l}0.008 \\
0 \\
0.008 \\
0.006\end{array}$ & $\begin{array}{l}0.087 \\
0.140 * * \\
0.079 \\
0.041\end{array}$ & $\begin{array}{l}0.072 \\
0.058 \\
0.068 \\
0.046\end{array}$ \\
\hline 1977 & $\begin{array}{l}\text { O } 191 \\
\text { CH } 591-36\end{array}$ & $\begin{array}{l}0.100 * * \\
0.023 * * *\end{array}$ & $\begin{array}{l}0.006 \\
0.002\end{array}$ & $\begin{array}{l}0.053 \\
0.010\end{array}$ & $\begin{array}{l}0.054 \\
0.016\end{array}$ \\
\hline 1978 & $\begin{array}{l}\text { Bc } 23 \\
\text { Bc } 9 \mathrm{~A} \\
\text { Bc } 9 \mathrm{~A} \times \mathrm{Bc} 23\end{array}$ & $\begin{array}{l}0.017 * * \\
0.101 * * * \\
0.029 * * *\end{array}$ & $\begin{array}{l}0.002 \\
0 \\
0.001\end{array}$ & $\begin{array}{l}0.004 \\
0.065 \\
0.017\end{array}$ & $\begin{array}{l}0.014 \\
0.036 \\
0.013\end{array}$ \\
\hline 1979 & $\begin{array}{l}\text { Bc } 23 \\
\text { Bc } 9 A \\
\text { Bc } 14 \\
\text { Bc } 6635 \\
\text { Bc } 9 \text { A X Bc } 23 \\
\text { Bc } 14 \times \text { Bc } 23 \\
\text { Bc } 6635 \times \text { Bc } 23 \\
\text { Bc } 9 \text { A X Bc } 6635\end{array}$ & $\begin{array}{l}0.043 * * * \\
0.086 * \\
0.123^{* * *} \\
0.164 * * * \\
0.044^{* * *} \\
0.101 * * * \\
0.051 * * \\
0.063 * * *\end{array}$ & $\begin{array}{l}0.001 \\
0.016 \\
0.006 \\
0.006 \\
0.001 \\
0.001 \\
0.002 \\
0.002\end{array}$ & $\begin{array}{l}0.030 \\
0.042 \\
0.063 \\
0.086 \\
0.023 \\
0.042 \text { * } \\
0.014 \text { * } \\
0.031\end{array}$ & $\begin{array}{l}0.015 \\
0.060 \\
0.065 \\
0.084 \\
0.019 \\
0.060 \\
0.040 \\
0.035\end{array}$ \\
\hline 1980 & $\begin{array}{l}\text { Bc } 23 \\
\text { Bc } 9 A \\
\text { Bc } 14 \\
\text { Bc } 6635 \\
\text { Bc } 9 A \times \text { Bc } 23 \\
\text { Bc } 14 \times \text { Bc } 23 \\
\text { Bc } 6635 \times \text { Bc } 23 \\
\text { Bc } 9 \text { A X Bc } 6635\end{array}$ & $\begin{array}{l}0.054 * * * \\
0.059 * * * \\
0.165 * * * \\
0.146 * * * \\
0.028 * * \\
0.046 * * * \\
0.021 * * \\
0.079 * * *\end{array}$ & $\begin{array}{l}0.005 \\
0.011 \\
0.086 \\
0.015 \\
0.001 \\
0.007 \\
0.002 \\
0.001\end{array}$ & $\begin{array}{l}0.039 * \\
0.021 * \\
0.046 \\
0.070 \\
0.016 \\
0.035 * \\
0.012 \\
0.032\end{array}$ & $\begin{array}{l}0.020 \\
0.049 \\
0.048 \\
0.092 \\
0.013 \\
0.019 \\
0.012 \\
0.048\end{array}$ \\
\hline
\end{tabular}

a TPHR is the total length of tunnels in $\mathrm{cm}$ in a plant divided by its height.

$\mathrm{b} *{ }^{* *},{ }^{* * *}$ : significant at the $0.05,0.01$, and 0.001 levels, respectively.

All cultivars in all years showed a significant effect of ECB artificial infestation on TPHR (Table 5). In all occasions, the presence of ECB increased TPHR as expected. In eight cases, a significant effect of stalk rot was found. In five instances, the presence of stalk rot decreased the TPHR confirming the observations from harvest damage. However, for the other three cases, the presence of stalk rot increased the TPHR. The impact of the presence of stalk rot on the feeding of ECB larvae thus remains unclear.

Yield was highly affected by the cultivar used and significant effects were found for ECB presence in 1975, 1976, 1979 and 1980. The presence of stalk rot had a significant effect $(P \leq 0.01)$ on yield only in 1979 (Table 2).
Significant effects of ECB artificial infestation on yield were found in less than half the cultivars and years evaluated. In all instances, however, the presence of ECB decreased yield significantly (Table 6). The presence of stalk rot was associated with significant decrease in the yield on five occasions but with an increase on another occasion.

The strong impact of ECB artificial infestation on leaf feeding and TPHR was expected. Leaf feeding reflects the establishment of the young larvae within the plant and as such the significance of this factor indicates that the artificial infestations were successful. TPHR is a measure of the development of the larvae within the plants and indicates that plants in ECB treatment plots had larvae within their 
stalks. For both these measures, the presence of stalk rot had no consistent effect. The feeding of young ECB larvae or their establishment in the stalk was not influenced by the presence of stalk rot. In New York State, interactions between ECB infestation and stalk rot caused by Colletotrichum graminicola (Ces.) Wils. varied between years and according to the stage at which the artificial infestation was made (Keller et al. 1986).

Differences in damage at harvest or yield between cultivars or years should reflect how individual cultivars react to ECB attack. As such, the results obtained for plant damage at harvest and yield are easier to explain. Years like 1975 and 1976 showed a large impact of the presence of ECB on both plant damage and yield for most cultivars. Three yugoslavian hybrids, $\mathrm{Bc} 14 \mathrm{XBc} 23, \mathrm{Bc} 6635 \mathrm{XBc} 23$ and Bc9AXBc6635, showed no significant effect on plant damage or yield following artificial infestation from ECB in 1979 but these effects appeared in 1980. Again, for these indices, the presence of stalk rot had no consistent effect.

From these results, it appears that although stalk rot can have a significant effect on plant damage and yield of maize, no consistent link exists between this infection and the presence of ECB. These results agree in general with those of Carson and Hooker (1981) and Foott: and Timmins (1983) who found no association between severity of stalk rot and ECB infestations, and so disagree with those of Christensen and Schneider (1950), Chiang

Table 6. Mean value of maize yield for plots with and without European corn borer and stalk rot

\begin{tabular}{|c|c|c|c|c|c|}
\hline \multirow[b]{3}{*}{ Year } & \multirow[b]{3}{*}{ Cultivars } & \multicolumn{4}{|c|}{$\begin{array}{l}\text { Mean yield } \\
\left(\mathrm{g} \mathrm{plant}^{-1}\right)\end{array}$} \\
\hline & & \multicolumn{2}{|c|}{ European corn borer } & \multicolumn{2}{|c|}{ Stalk rot } \\
\hline & & With & Without & With & Without \\
\hline 1975 & $\begin{array}{l}\text { CO } 239 \\
\text { O } 191 \\
\text { Stewart } 2606 \\
\text { Stewart } 2704\end{array}$ & $\begin{array}{c}40.4 * * * a \\
0 * * * \\
96.8 * * * \\
125.4 * * *\end{array}$ & $\begin{array}{r}90.9 \\
53.7 \\
158.8 \\
181.8\end{array}$ & $\begin{array}{c}59.6 \\
26.7 \\
129.4 \\
148.8 *\end{array}$ & $\begin{array}{r}71.7 \\
27.1 \\
126.2 \\
158.5\end{array}$ \\
\hline 1976 & $\begin{array}{l}\text { CO } 239 \\
\text { T } 341 \\
\text { MR21 X ZPR2077 } \\
\text { R588 X T146 }\end{array}$ & $\begin{array}{l}77.2^{* *} \\
42.6^{*} \\
83.6^{* * *} \\
105.4^{* *}\end{array}$ & $\begin{array}{r}92.2 \\
50.8 \\
112.6 \\
112.4\end{array}$ & $\begin{array}{c}85.7 \\
46.6 \\
95.9 \\
105.7 * *\end{array}$ & $\begin{array}{r}83.7 \\
46.7 \\
100.2 \\
112.1\end{array}$ \\
\hline 1977 & $\begin{array}{l}\text { Q } 191 \\
\text { CH } 591-36\end{array}$ & $\begin{array}{l}25.3 \\
14.4\end{array}$ & $\begin{array}{l}36.8 \\
12.9\end{array}$ & $\begin{array}{l}30.6 \\
12.2\end{array}$ & $\begin{array}{l}31.5 \\
15.2\end{array}$ \\
\hline 1978 & $\begin{array}{l}\text { Bc } 23 \\
\text { Bc } 9 \mathrm{~A} \\
\text { Bc } 9 \mathrm{~A} \times \mathrm{Bc} 23\end{array}$ & $\begin{array}{r}42.5 \\
55.1 \\
140.1\end{array}$ & $\begin{array}{r}41.4 \\
57.5 \\
148.9\end{array}$ & $\begin{array}{r}36.4^{*} \\
54.9 \\
141.1\end{array}$ & $\begin{array}{r}47.5 \\
57.6 \\
147.9\end{array}$ \\
\hline 1979 & $\begin{array}{l}\text { Bc } 23 \\
\text { Bc } 9 A \\
\text { Bc } 14 \\
\text { Bc } 6635 \\
\text { Bc } 9 A \times \text { Bc } 23 \\
\text { Bc } 14 \times \text { Bc } 23 \\
\text { Bc } 6635 \times \text { Bc } 23 \\
\text { Bc } 9 \text { A X Bc } 6635\end{array}$ & $\begin{array}{l}16.6 \\
27.2 \\
22.0 \\
14.9 * * * \\
79.4 \\
97.4 \\
96.9 \\
84.2\end{array}$ & $\begin{array}{r}17.2 \\
32.9 \\
34.3 \\
37.3 \\
92.7 \\
113.7 \\
95.4 \\
81.8\end{array}$ & $\begin{array}{l}10.1 * \\
29.1 \\
24.5 \\
21.9 * \\
80.4 \\
95.6 \\
97.7 \\
80.0\end{array}$ & $\begin{array}{r}23.7 \\
31.0 \\
31.7 \\
30.3 \\
91.8 \\
115.5 \\
94.7 \\
86.0\end{array}$ \\
\hline 1980 & $\begin{array}{l}\text { Bc } 23 \\
\text { Bc } 9 A \\
\text { Bc } 14 \\
\text { Bc } 6635 \\
\text { Bc } 9 A \times \text { Bc } 23 \\
\text { Bc } 14 \times \text { Bc } 23 \\
\text { Bc } 6635 \times \text { Bc } 23 \\
\text { Bc } 9 A \times \text { Bc } 6635\end{array}$ & $\begin{array}{l}31.1 \\
42.4 \\
29.3 * * \\
32.0 \\
104.4 \\
103.7 * * \\
113.0 \\
91.0 * *\end{array}$ & $\begin{array}{r}36.2 \\
38.4 \\
43.7 \\
32.1 \\
101.1 \\
125.1 \\
120.8 \\
102.6\end{array}$ & $\begin{array}{c}30.0 \\
40.8 \\
37.3 \\
34.8^{*} \\
103.3 \\
109.2 \\
111.9 \\
97.0\end{array}$ & $\begin{array}{r}37.3 \\
40.0 \\
35.8 \\
29.3 \\
102.1 \\
119.6 \\
121.9 \\
96.6\end{array}$ \\
\hline
\end{tabular}

a $* *^{*}, * * *$ : significant at the $0.05,0.01$, and 0.001 levels, respectively. 
and Wilcoxson (1961) and Jarvis et al. (1982). Those observations were made on the bivoltine strain of $O$. nubilalis and the present results are based on observations of the univoltine strain that is dominant in Québec.

\section{ACKNOWLEDGEMENTS}

The authors wish to thank Dr. M. Rojć, maize breeder at the Institute for Breeding and Production of Field Crops of Zagreb, Yugoslavia, for providing seeds of the inbreds and experimental hybrids evaluated from 1978 to 1980; the International Working Group on Ostrinia (IWGO) for the other inbreds and Dr. G. E. Jones, Research Director of the Canadian Seed Corn Production Company, Stewart Seeds Ltd, for having supplied the two commercial hybrids Stewart 2606 and 2704. We also acknowledge the technical assistance of Mario Boivin of the Agriculture Canada Research Station in Saint-Jean-sur-Richelieu.

\section{REFERENCES}

Bergstrom, G.C., B.S. Croskey, and T.I. Carruthers. 1983. Synergism between Colletotrichum graminicola and European corn borer in stalk rot of corn in New York. Phytopathology 73: 842 (Abstract)

Carson, M. L., and A. L. Hooker. 1981. Inheritance of resistance to stalk rot of corn caused by Colletotrichum graminicola. Phytopathology 71: 1190-1196

Chez, D., M. Hudon, and M.S. Chiang. 1977. Resistance of maize to European corn borer (Ostrinia nubilalis) and to stalk rot caused by Gibberella zeae. Phytoprotection 58: 5-17.

Chiang, H.C., and R.D. Wilcoxson. 1961. Interaction of the European corn borer and stalk rot in corn. J. Econ. Entomol. 54: 850852.

Chiang, M.S., M. Hudon, A. Devaux, and I. Ogilvie. 1987. Inheritance of resistance to Gibberella ear rot in maize. Phytoprotection 68: 29-33.

Christensen, J.I., and C.L. Schneider. 1950. European corn borer (Pyrausta nubilalis $\mathrm{Hbn}$.) in relation to shank, stalk and ear rots of corn. Phytopathology 40: 284-291.
Dicke, F.F., and W.D. Guthrie. 1988. The most important corn insects. Pages 767-867 in G.F. Sprague and J.W. Dudley (eds.), Corn and corn improvement. Am. Soc. Agronomy, Crop Sci. Soc. Am., Soil Sci. Soc. Am. Madison, Wisc.

Foott, W.H., and P.R. Timmins. 1983. The severity of stalk rot of grain corn in relation to infestations of bivoltine strain of the European corn borer Ostrinia nubilalis (Lepidoptera: Pyralidae). Can. Entomol. 115: 1235-1237.

Guthrie, W.D. 1971. Resistance of maize to second-brood European corn borers. Proc. Hybrid Corn. Ind. Res. Conf. 26: 165-179.

Guthrie,W.D.,E.D.Raun, F.F. Dicke, G.R. Pesha, and S.W. Carter. 1960. Laboratory production of European corn borer egg masses. lowa State J. Sci. 40: 65-83.

Hudon, M., and E. J. LeRoux. 1986. Biology and population dynamics of the European corn borer (Ostrinia nubilalis) with special reference to sweet corn in Quebec. 1. Systematics, morphology, geographical distribution, host range, economic importance. Phytoprotection 67: 39-54.

Hudon, M., M.S. Chiang, and D. Chez. 1979. Resistance and tolerance of maize inbred lines to the European corn borer Ostrinia nubilalis (Hübner) and their maturity in Quebec. Phytoprotection 60: 1-22.

Jarvis, J.L., R.L. Clark, and W.D. Guthrie. 1982. Effect of second-generation European corn borer on resistance of maize to Diplodia maydis. Phytopathology 72: 1149-1152.

Jarvis, J.L., R.L. Clark, W.D. Guthrie, E.C. Berry, and W.A. Russell. 1984. The relationship between second-generation European corn borers and stalk rot fungi in maize hybrids. Maydica 29: 247-263.

Keller, N.P., G.C. Bergstrom, and R.I. Carruthers. 1986. Potential yield reductions in maize associated with an anthracnose/European corn borer pest complex in New York. Phytopathology 76: 586-589.

Krueger, W., and W. Weiler. 1977. [The occurrence of stalk rot on maize cultivars following stalk borer infestation (Ostrinia nubilalis)] (in German). Z. Pflanzenkr. Pflanzenschutz (J. PI. Disease Prot.) 84: 602-611.

McKeen, W.E. 1951. A corn root and stalk-rot complex hitherto known as Gibberella zeae stalk rot. Phytopathology 41: 26 (Abstract)

Michaelson, M.E., and J.I. Christensen. 1953. Reduction in yield of corn due to stalk rot. Phytopathology 43: 479 (Abstract)

Nyhus, K.A., W.A. Russell, and W.D. Guthrie. 1988. Response of two maize synthetics to recurrent selection for resistance to firstgeneration European corn borer (Lepidoptera: Pyralidae) and Diplodia stalk rot. J. Econ. Entomol. 81: 1792-1798. 
SAS Institute Inc. 1985. SAS user's guide: statistics. SAS Institute, Cary, N. C.

Shurtleff, M.C. 1980. Compendium of corn disease. Am. Phytopathol. Soc. (2nd ed.), St.Paul, Min.. 105 pp.

Smith, F.L., and C.D. Madsen. 1949. Susceptibility of inbred lines of corn to Fusarium ear rot. Agron. J. 41: 347-348.

Taylor, G.S. 1952. Stalk-rot development in corn following the European corn borer. Phytopathology 42: 20-21.

Wilcoxson, R.D. 1962. Stalk rot in relation to yield in corn. Phytopathology 52: 416-418.

Young, H.C., Jr. 1943. The toothpick method of inoculating corn for ear and stalk rots. Phytopathology 33: 16 (Abstract) 